
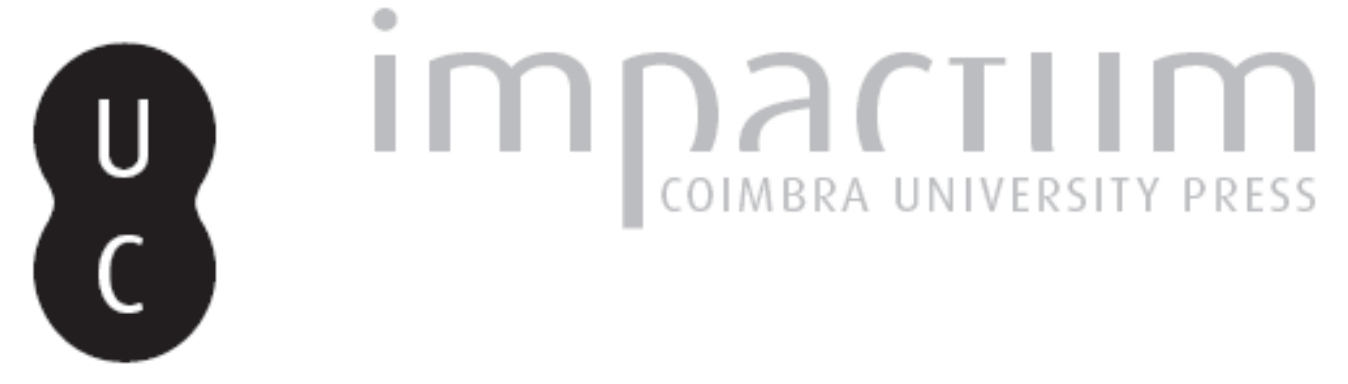

\title{
Sátira e o cepticismo: configuração de personagens em Mário de Carvalho
}

Autor(es): $\quad$ Simões, Maria João

Publicado por: Faculdade de Letras da Universidade de Coimbra

URL persistente:

URI:http://hdl.handle.net/10316.2/32737

DOI:

DOI:http://dx.doi.org/10.14195/0870-4112_7_9

Accessed : $\quad$ 26-Apr-2023 13:42:56

A navegação consulta e descarregamento dos títulos inseridos nas Bibliotecas Digitais UC Digitalis, UC Pombalina e UC Impactum, pressupõem a aceitação plena e sem reservas dos Termos e Condições de Uso destas Bibliotecas Digitais, disponíveis em https://digitalis.uc.pt/pt-pt/termos.

Conforme exposto nos referidos Termos e Condições de Uso, o descarregamento de títulos de acesso restrito requer uma licença válida de autorização devendo o utilizador aceder ao(s) documento(s) a partir de um endereço de IP da instituição detentora da supramencionada licença.

Ao utilizador é apenas permitido o descarregamento para uso pessoal, pelo que o emprego do(s) título(s) descarregado(s) para outro fim, designadamente comercial, carece de autorização do respetivo autor ou editor da obra.

Na medida em que todas as obras da UC Digitalis se encontram protegidas pelo Código do Direito de Autor e Direitos Conexos e demais legislação aplicável, toda a cópia, parcial ou total, deste documento, nos casos em que é legalmente admitida, deverá conter ou fazer-se acompanhar por este aviso.

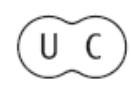




\section{Sociedade em Tumulto}

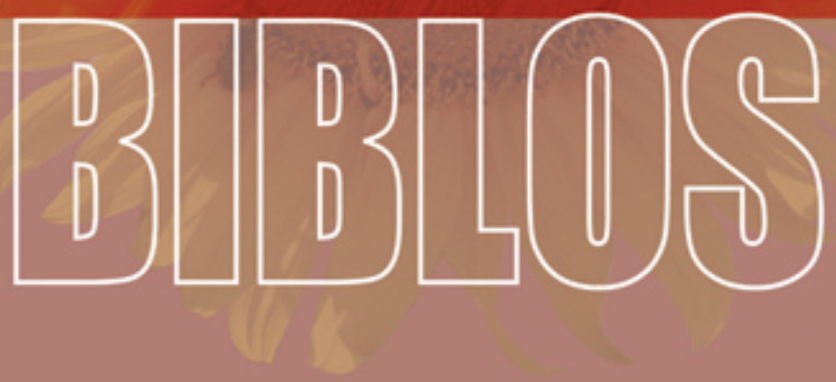

REVISTA DA FACULDADE DE LETRAS

UNIVERSIDADE DE GOIMBRA 
Maria João Simões

Universidade de Coimbra

\section{SÁTIRA E O CEPTICISMO: CONFIGURAÇÃO DE PERSONAGENS EM MÁRIO DE CARVALHO}

\section{Resumo}

A personagem constitui uma importante categoria ficcional à qual os estudiosos têm dado uma renovada atenção em parte devido ao relevo que ela vem adquirindo nas abordagens da "escrita criativa", mas também nos cursos para guionistas e outros domínios artisticos.

Mais do que adoptar um modelo teórico-conceptual de análise da personagem - seja ele de índole estruturalista, humanista, estético-historicista, funcional, sociológica, psicológica, ou qualquer outra - defende-se, de acordo com Uri Margolin, uma perspectiva integrativa dos diferentes modelos e concepções da personagem para avaliar e apreciar as personagens do mundo ficcional de Mário de Carvalho.

Analisar-se-á, então, a configuração específica e individualizada de algumas das personagens das obras Casos do Beco das Sardinheiras, Fantasia para Dois Coronéis e Uma Piscina, Era Bom Que Trocássemos Umas Ideias Sobre o Assunto e Um Deus Passeando pela Brisa da Tarde, mas também a sua representatividade social, a sua funcionalidade estética dentro da própria obra e ainda o modo como concorrem para a dimensão filosófica das obras referidas.

Palavras-chave: personagem, teoria e conceptualização da personagem, função da personagem.

\section{Abstract}

Character is an important fictional category which is, presently, the object of an increasing interest on the part of different scholars due to the importance it has gained in different "creative writing" aproaches, as well as in the curricula for script writers and other arts courses.

Instead of adopting a theoretical-conceptual model of character analysis - be it structural, humanistic, aesthetic-historical, functional, sociological, psichological or any other type - this article defends, folowing Uri Margolin, the application of a perspective which integrates different models and character 
conceptualizations in order to evaluate, and appreciate, the characters of the fictional world of Mário de Carvalho.

The article analyzes not only the specific and individualized configuration of some of the characters of the works Casos do Beco das Sardinheiras, Fantasia para Dois Coronéis e Uma Piscina, Era Bom Que Trocássemos Umas Ideias Sobre o Assunto and Um Deus Passeando pela Brisa da Tarde, but also their social representativity, aesthetic functionality and contribution to the philosophical dimension of each of the works mentioned.

Keywords: character, character theory and conceptualization, role of character.

Le personnage décolle le Moi, le laisse flotter dans un espace symbolique plutôt qu'expréssif-indiciel, il apporte la coupure sémiotique et "l'autre scène".

Daniel Bougnoux

Há tanta personagem de romance que conheço melhor por dentro de que esse eu-mesmo que há vinte anos passava por aqui!

"Realidade"- Álvaro de Campos

\section{Sentir e apreciar personagens}

A imagem do autor criando as suas personagens como o artesão molda as suas figuras a partir da greda informe surge intermitentemente na nossa memória, embora saibamos que se trata de uma imagem simplificadora. Parece que em algumas personagens a "massa aderente" persiste apanhando o incauto leitor - e às vezes até o próprio autor que não se consegue libertar senão a custo do visco que elas vão fiando nas suas teias. Com efeito, numa espécie de revisitação do mito do golem, certas personagens, cujo desenho ganha consistência ao longo da leitura, conquistam um espaço na nossa memória, e teimosamente, persistem nela mesmo depois de abandonada a leitura e quando já se esfumam os contornos mais pormenorizados das intrigas.

Levantam-se então duas questões: como e porque é que isto acontece? Mas já estas duas questões desencadeiam uma outra: o desmontar e o explicar deste processo, de certa forma encantatório, não destruirá o encanto que as personagens nos proporcionam?

Faculdade de Letras | Universidade de Coimbra 
Coloca-se muitas vezes este falsa clivagem entre o sentir estético e o olhar informado do conhecedor de uma determinada poética e dos seus procedimentos, mas, na verdade, um maior conhecimento do artístico não impede o sentir. Kendall Walton, por exemplo, na obra Mimesis as Make-Believe, ao expor a sua teoria da representação artística, reconhece a perspectiva dual do apreciador, o qual é capaz de participar no jogo ficcional e, ao mesmo tempo, observar o modo como está montado ou é composto esse jogo:

The appreciator's perspective is a dual one. He observes fictional worlds as well as living in them; he discovers what is fictional as well as fictionally learning about and responding to characters and their situations. (1990: 273)

Intrinsecamente ligados, jogo ficcional e observação dependem um do outro; só analiticamente o primeiro visa a experiência estética, e a segunda o saber sobre a poïesis ou o fazer específico de cada arte. Não existem separadamente - condicionam-se.

Indispensável à especificidade estético-literária surge, então, a destrinça entre apreciação estética e apreciação artística apresentada por Gérard Genette no segundo volume de L'CEuvre de l'Art, no seguimento daquela outra distinção que o autor estabelece entre a mera atenção estética e a ponderada apreciação estética ${ }^{1}$.

Alguns aspectos destas diferenças são também levantados por Martin Seel, o qual, ao considerar a ideia de obra de arte como uma "configuração articulada", analisa vários modos de articulação da obra de arte com o mundo e estabelece três tipos de percepção estética: contemplativa, corresponsiva e imaginativa. Mas é preciso reter a ideia de que estas diferenças não são entendidas pelo autor como excludentes, sendo necessário, pelo contrário, entendê-las como um continuum transitável. Se às obras de arte, entendidas como "construções imaginativas" (1992: 131), se pode aceder por percepção imaginativa,

${ }^{1}$ Segundo Jean-Marie Schaeffer, a teoria especulativa da arte elidiu a distinção entre a esfera da estética e a esfera artística (1992: 344). Este autor reconhece a grande importância da destrinça genettiana entre intencional e atencional, que permite estabelecer diferentes tipos de julgamento estético: por um lado, aqueles que são feitos sobre objectos intencionalmente estéticos ou, então, sobre objectos não intencionalmente estéticos, ainda que utilitária e intencionalmente feitos, mas vistos agora numa perspectiva estética; e, por outro lado, aqueles que são realizados sobre o que não é intencionalmente feito, apenas existe (Schaeffer, 1996: 371).

Faculdade de Letras | Universidade de Coimbra 
isso não exclui a manifestação dos outros tipos de percepção. Aí reside, de certa forma, a complexidade das obras de arte:

En vertu de son unité esthétique, l'œuvre d'art donne l'occasion à l'homme de se rencontrer soi-même selon ses possibiliés fondamentales: la distance contemplative à l'égard du monde vécu, la participation corresponsive à ce monde, la perspective imaginative ouverte sur lui. Les œuvres d'art sont des objets esthétiques, dans lesquelles ces possibilités s'imbriquent de multiples façons. (Seel, 1992: 136)

Se o facto de se desvendar o modo como a personagem nos impressiona pode trazer uma compreensão diferente dela e até mesmo uma apreciação mais gostosa, será importante estar consciente dos vários níveis e das diferentes dimensões relativamente aos quais as podemos analisar.

Ora,sãomúltiplos os modelos teórico-conceptuais sobre apersonagem e são também diferentes os esquemas e as formas de os agrupar. É certo que a variedade de personagens, originada pela liberdade criativa dos artistas, constantemente põe em causa modelos rígidos de análise; porém, também é certo que esses modelos são heuristicamente produtivos não só no seu tempo como em momentos posteriores. À laia de lampejo prévio, e apenas para um esclarecimento inicial, poder-se-á reter as distrinças feitas por John Frow e por Gerald Mead. O primeiro aponta a dicotomia entre a concepção teórica humanista e a estruturalista relativamente à personagem e também as concepções estético-historicistas. Como alternativa fala ainda das teorias psicoanalíticas de abordagem da personagem. Já Gerald Mead (1990: 440) distingue entre a perspectiva referencial (onde inclui a biográfica, a psicológica e a sociológica) e a perspectiva textual (com várias vertentes: estrutural, funcional, imanente e actancial).

Curiosamente, alguns teóricos acabam de certa forma por reconhecer alguma vantagem na consideração conjunta das várias teorias, insistindo na sua complementaridade. Gerald Mead, por exemplo, afirma que "although there may be important theoretical differences between [the] two approaches, in practice they are not incompatible". Por seu turno, também Uri Margolin (2005: 57) põe em dúvida o facto de as diferentes teorias sobre personagens se excluírem, e, apoiando-se em James Phelan, defende uma perspectiva integrativa.

Partindo desta possibilidade integrativa, abordar-se-ão neste trabalho algumas personagens de Mário de Carvalho e, para esta abordagem, convocar-se-ão eclecticamente as diferentes teorias 
sobre as personagens sempre que tal se entender útil para um melhor discernimento delas. Preside a este eclectismo a convicção de que são as próprias personagens que suscitam diferentes abordagens, ora se salientando por uma determinada função estruturante dentro de um universo ficcional, ora apelando para um mais intenso desejo de identificação por parte do leitor, catapultando a abordagem e a análise para o lado da recepção.

\section{Personagem e identificação categorial}

Observar-se-á, primeiramente, a obra Casos do Beco das Sardinheiras, título sob o qual Mário de Carvalho recolhe um conjunto de pequenas narrativas de estranhos acontecimentos. A narração abre sempre com o sintagma nominal "Uma ocasião" utilizado pelo narrador como bordão para contar cada um dos insólitos casos ocorridos no Beco: um homem que engoliu a lua, um gato que é uma pantera, uma corda que sobe para o céu, uma misteriosa pedra negra, etc. Sempre disposto a resolver as "escanifobéticas" complicações que surgem na atribulada vida do Beco, surge o Zeca da Carris que é talvez a personagem com mais destaque nesta obra, logo secundada pelo Zé Metade. Mas dizer que é mais importante não quer dizer que esta seja uma personagem grandiosa: em termos miméticos ele representa um simples morador de bairro pobre - é um representante da "arraia-miúda", como diz o autor no "Epílogo". Como as outras personagens, ele representa o meio ambiente popular de Alfama ou da Mouraria, onde as vidas dos moradores e vizinhos se entrelaçam num espírito marcado por um misto de interajuda e de pequena inveja, de colaboração, mas também de mesquinhez e grosseria.

Como é que esta personagem atrai o leitor? E porquê?

Ela suscita uma reacção mesclada, quase contraditória: por um lado, o leitor identifica-se com a lei de sobrevivência à qual a personagem obedece, uma vez que o Zeca da Carris está sempre apto a resolver os problemas que surgem no Beco; mas, por outro lado, ele sente uma certa distância, julga-se superior às soluções fáceis e simplistas adoptadas por Zeca que, por vezes, não resultam - como acontece relativamente ao caso do acidente do Quim Ambrósio que, por ter apanhado com uma telha em cima do lado esquerdo da cabeça, ficou falando uma "algaravia" que ninguém entendia e que Zeca tenta resolver com uma pancada idêntica no outro lado da cabeça.

Já o porquê da sua atracção nos remete para outro nível da projecção mimética da personagem, a saber, aquilo que ela representa 
em termos epistemológicos e filosóficos. Ora, neste sentido, aquilo que o Zeca da Carris representa é o que nos prende ao quotidiano. Isto, em si, parece pouco, mas no caso desta obra não o é, porque o quotidiano aqui representado está eivado de irrealismo: muito do que acontece no Beco é inexplicável segundo as leis racionais, sendo o suposto real constantemente atravessado pelo fantástico, o qual, em vez de ser considerado num plano de conhecimento diferente, é incorporado e absorvido pelo plano da realidade. (É o que acontece, por exemplo, quando a máquina de costura comprada pela mulher de Zeca revela ter a capacidade de gelar tudo numa área à sua volta em forma de paralelepípedo e, perante este insólito facto, o casal decide aproveitar este fenómeno utilizando a máquina de costura como congelador.) Assim, o sentido desse quotidiano representado transmuta-se através do fantástico, reduzindo ao absurdo a trivialidade do viver quotidiano. Com este jogo atinge-se, então, uma questionação do absurdo da vida, uma questionação distanciada pelo cómico e pelo poder subversivo do fantástico.

Ao nível discursivo, este questionar da existência encontra eco na expressão "não devemos confundir o género humano com o Manuel Germano" que, segundo Pedro Mexia, é "um aviso contra universalismos e moralismos", mas que, para além de indicar a não dissolução do "eu individual" no "eu social", aponta também a relação difícil entre ambos. Assim se compreende a razão pela qual, textualmente, a personagem é conhecida de modo familiar pelo diminutivo Zeca e pelo complemento determinativo "da Carris": por um lado, o indivíduo na sua singularidade, por outro lado, aquilo que lhe empresta essa ancoragem no social. Por sua vez, a linguagem identifica-o como pessoa simples e de trabalho, que tem necessidade de integrar rapidamente o inusitado no quotidiano, como acontece no caso da máquina de costura geladeira ao incorporar o inexplicável no real para que tudo regresse à normalidade. De facto, no início do texto, primeiro delimita o problema

- O que me rala - comentou o Zeca - é não saber se isto é da máquina ou se é do sítio. Ora arredem-se pra lá! (p. 49) (...)

e, depois, incorpora-o na normalidade:

- Bom o espectáculo que havia a ver já está visto. Agora agradecia que me desamparassem a loja que amanhã é dia de trabalho. (p. 50). 
A personagem ganha complexidade porque nela coalescem realismo e fantástico. Com efeito, para além da sua ancoragem no real, o seu desenho está embutido na categoria do fantástico, desencadeando assim uma apreciação estética que está em consonância com a apreciação categorial $^{2}$ requerida pela obra. Tal funcionalidade põe em evidência como a apreciação artística opera activando preenchimentos categoriais e genológicos.

Embora esta obra apresente alguns laivos satíricos, o predicado estético predominante é o fantástico e não o satírico.

\section{Individuação e marcas distintivas das personagens}

Já em duas outras obras de Mário de Carvalho - Era Bom Que Trocássemos Umas Ideias Sobre o Assunto, de 1995, e Fantasia para Dois Coronéis e Uma Piscina, de 2003 - a categoria estética prevalecente é o satírico. Traçada como uma profunda sátira ao Portugal contemporâneo, Fantasia é uma obra que apresenta sobretudo personagens planas, a começar pelos dois coronéis já reformados e respectivas esposas que se reencontram no Alentejo. O Coronel Maciel Bernardes é, apesar disso, uma personagem um pouco mais importante, o que é atestado por dois aspectos: primeiro, pelo facto de o narrador o colocar logo em cena no contexto cronotópico da acção principal e o dar a conhecer ao leitor "de chofre" - tomando conta da sua piscina, lendo o jornal e beberricando o seu uísque; segundo, porque o autor, logo a seguir, lhe concede várias páginas de caracterização directa, numa analepse narrativa que fornece ao leitor a explicação do seu posto e o modo como chegou ao casamento, etc.. Através desta analepse ficamos logo a saber que o Coronel é muito dado à "tagarelice" - um mal de que sofre todo o Portugal, como o autor afirma a abrir o romance:

${ }^{2}$ Gérard Genette (1997: 190) aponta como distintivo da candidatura específica das obras de arte a "pregnância dos dados técnicos", sendo "a função artística o lugar por excelência de interacção entre o estético e o técnico". Assim, um dos sintomas passíveis de estimular a atenção estética será aquilo que designa por "saturação semântica" (idem, 69). Mas, de acordo com o teórico francês, para além da atenção, é imprescindível à relação estética essa outra dimensão que é a apreciação, que ganha contornos específicos na relação artística, por causa dessa pregnância técnica.

Faculdade de Letras | Universidade de Coimbra 
Assola o país uma pulsão coloquial que põe toda a gente em estado frenético de tagarelice, numa multiplicação ansiosa de duos, trios, ensembles, coros. (...) O país fala, fala, desunha-se a falar, e pouco do que diz tem o menor interesse. O país não tem nada a dizer, a ensinar, a comunicar. O país quer é aturdir-se. E a tagarelice é o meio de aturdimento mais à mão." (2003: 11).

Ora o Coronel Bernardes, apesar de brandir contra este costume, "revela-se, ele mesmo, um conversador compulsivo" (2003: 25). Fora, precisamente, esse gosto pela conversação que o levara a anotar "episódios" num caderninho quando cumpria serviço como capitão no ultramar, para poder contar mais tarde todas as histórias ${ }^{3}$. Caindo, depois, no meio da revolução adopta rapidamente a sua retórica de alarido, "alegre e algo confusa":

E em tanto comício, tanta assembleia, tanta sessão de esclarecimento, o coronel, que o não era ainda, confirmou o seu gosto pela argumentação, pela dissertação, pela dialéctica. (2003: 27)

Já na reforma, afina o seu poder de argumentação ficando a administrar o condomínio do prédio onde vivia e onde massacra os condóminos com o exercício da sua habilidade retórica e persuasiva. Para além desta analepse inicial, o leitor terá ocasião de ir observando, ao longo da acção do romance, este gosto pela tagarelice nas longas e remansadas conversas que tem sobretudo com o seu colega Coronel Lencastre. Tratando-se de uma caracterização indirecta, caberá aos leitores inferir o seu perfil caracteriológico: o seu machismo mitigado (por algumas concessões a bem da sua própria comodidade), o seu conservadorismo ideológico, mas sobretudo a superficialidade da sua cultura, a vacuidade da sua forma de pensar e a loquacidade prazenteira característica de um autocomprazimento que roça a infantilidade (a arma colocada por baixo da travesseira substitui - como esclarece o narrador - o ursinho de peluche). Não espanta portanto a sua reacção emotiva à traição da mulher, mesmo ali ao pé do seu nariz, com um jovem vedor que ele próprio chamara para encontrar água no monte, a fim de fazer uma piscina.

${ }^{3}$ Este caderninho foi o que lhe salvou a vida, pois quando foi atingido por um estilhaço de granada o caderninho ficou estralhaçado, mas ele não. Esta perda, porém, ganha aqui um significado simbólico, uma vez que, a partir desse momento, ele nunca mais irá poder contar "histórias" de uma forma documentada e mais séria. 
Uma síntese caracteriológica desta personagem teria pois de dar conta não só dos elementos que concorrem para a sua caracterização (física e psicológica), mas também teria de referir o seu papel e a sua funcionalidade na economia da obra e teria ainda de considerar a forma como o autor conduz a sua recepção pelo leitor.

Cumprindo este desidério, podemos dizer que Coronel Maciel Bernardes é uma personagem da obra Fantasia para Dois Coronéis e Uma Piscina e que, num país de faladores como o que esta obra satiriza, o Coronel Maciel Bernardes é mais um "conversador compulsivo", com o treino que lhe dão as histórias do serviço militar, a experiência das andanças pela retórica apaixonada do tempo da revolução, pelo refinar da prática argumentativa na direcção de um condomínio e depois a retórica como pachorrento e aprazível entretenimento de militar reformado. Faz o papel de marido conservador, por vezes comodistamente permissivo, e ainda de marido traído furioso; representa a vacuidade de uma classe média, oriunda de diversas profissões, que se reforma bastante cedo e que fica quase vegetando, sem ter grande coisa para fazer para além da maledicência. a sua funcionalidade na obra relativamente à dominante satírica é evidente e, logicamente, o leitor é conduzido a tecer sobre ele uma opinião crítica e distanciada.

Diferente já, é o caso de sua mulher a personagem Maria das Dores. Esta ousada figura feminina tem direito a caracterização física pormenorizada: enquanto jovem, ela surpreendia com os seus gestos bruscos", era "morena, seca, alta, usava lentes de uma espessura que pareciam iô-iôs", mas tinha um trejeito de boca engraçado" e "uma maneira de inclinar levemente a cabeça, à pardalito" que agradaram o então Major. Desde que se conheceram no baile de debutantes no Estoril, o que mais os aproximou foi o "desembaraço de linguagem" de Maria das Dores: uma linguagem desbragada, sem pruridos, eivada de regionalismos, de calão e de asneiras - apesar de ser filha de "um terratenente" alentejano "com dois "de" e um "e" no apelido" (2003: 30).

Paradoxalmente, quanto ao primeiro aspecto $-\mathrm{o}$ ponto de vista físico - a personagem torna-se mais interessante para o leitor precisamente por causa da irregularidade da sua aparência - e não apesar dela. Como relembram Johan F. Hoorn e Elly A. Konisn (2003: 253), a tendência comum é considerar fisicamente mais belo o mais regular e simétrico em relação à média; mas, como já Gombrich e Leyton (entre outros) assinalaram, "em arte e na ficção, maiores ou mais brandos desvios da simetria, da regularidade e da harmonia são por vezes mais apreciadas que a simetria perfeita". 
Se algumas características físicas são importantes na configuração desta personagem, o que sobressai, no seu caso, é o segundo aspecto, ou seja, é claramente a marca discursiva, demonstrando assim aquilo para que John Frow (1986: 245) chama a atenção: "characteres (...) tend to be also the subjects of discourse in their own right". Trata-se de um processo de individuação, se tivermos em conta a opinião de Amie Thomasson $(2003 ; 146)$ quando distingue três diferentes aspectos do estatuto ontolológico das personagens, a saber, "their existence and survival conditions, identity and individuation". De facto, o que singulariza esta personagem no romance é a sua língua viperina e desbragada, invulgar numa mulher. Se se adoptar numa perspectiva de abordagem mais funcionalista e mais estruturalista, este aspecto tem como objectivo criar um factor de diversão, mas também serve a intenção subversiva da sátira. Aliás, a personagem manifesta uma tal propensão disruptiva que chega a interpelar o autor e a perguntar-lhe se tem medo de escrever sobre ela, desenhando assim uma metalepse narrativa, uma vez que se derrogam os limites ficcionais, como já se analisou anteriormente ${ }^{4}$.

Este casal - cuja relação se pauta por um acordo tácito da concessão de algum espaço livre - aparece por assim dizer duplicado num outro casal: o do Coronel Lencastre e sua mulher. Porém, na economia da obra, este outro par proporciona um contraponto funcional em termos de conflito entre gerações, pois através dele autor consegue trazer para o romance a personagem mais caricatural da sua obra, moldada como uma espécie de pot-pourri de cómico, ridículo, burlesco e grotesco colocado ao serviço da sátira. Trata-se do filho do casal, Nelson, que, embora já com quarenta e dois anos, é amante dos tags com os quais pressupostamente fustiga o mundo burguês, pois, em seu entender, servem "pra desconstruir, para emporqueirar e dar sobressaltos". A configuração da personagem é feita com base no seu discurso: a personagem ganha vida pelo discurso. Trata-se de um virulento pastiche, que, como se sabe, ao contrário da paródia, visa a imitação - neste caso a imitação de um discurso pretensamente contestatário. A personagem representa o eterno adolescente auto-promovido a anarco-

${ }^{4}$ Uma abordagem de como Maria das Dores acciona este jogo ficcional da metalepse foi realizada em artigo anterior - cf. Simões, 2006: 84,85. Gérard Genette a designa de "metalepse" esse baralhar das fronteiras que separam as instâncias narrativas de uma e de outra parte do dispositivo enunciativo - cf. Genette, 2004: 10.

${ }^{5}$ Idem, p. 74. 
revolucionário - um pressuposto representante de uma "cultura de contestação", como ele explica num “enternecedor” discurso:

Vá lá pai, seja tolerante, que eu falo à moderna, linguagem viva, do povo mesmo, percebes? (...) É assim: eu é que não fossilizei no tempo, essa é que é essa, eu sou desenrascado, abertura prò mundo que está a mudar (...), meus, agora vocês, eu compreendo, já há a artrose, escoliose, ancilose, (...) é assim: não podem perceber, vão à janela e vejam-me esses muros, as portas dos prédios, os candieiros, o camandro, pá, lá está o meu, eu tou a deixar a minha marca nas paredes, e há uns gajos que sabem que sou eu, o Lencastre, o filho do coronel que riscou aquilo e que impediu a burguesia de ter ideias incolores contra os muros brancos, muro liso não tem expressão, os tags, atenção, atenção, não os grafitti, são vida e libertação, o grafitte amocha, faz o jeito ao burguês, tem harmonia, cores, armado ao artístico, o tag não!, é pra desconstruir, para emporqueirar e dar sobressaltos. A volúpia do perigo, pá, nunca ouviu falar?, assim mesmo, pá, mas porque é que o pai há-de ter esse feitio?, (...) isto é vida, a nova cultura, hip-hop, man, que lá fora, como é que é?, os museus estão cheios de hip-hop, só cá é que é esta merda tradicionalista, pequeno-burguesa, tudo certinho, tudo direitinho e o caraças (...) (Carvalho, 2003:73-74)

\section{4. "Identificação irónica" com a personagem: um paradoxo?}

Nesta obra, a maior parte das personagens não suscitam senão uma apreciação distanciada, por parte dos leitores; algumas há, porém, que conseguem suscitar uma certa dose de identificação que, no entanto, é sistematicamente posta em causa, numa espécie de volteio enredado, e quase parodoxalmente - elas suscitam aquilo que Robert Jauss chama, algo contraditoriamente 6 , "identificação" irónica:

Por identificación irónica entendemos un nivel de recepcción estética, en el que al espectador o al lector se le traza sólo una identificación esperable que, luego, es ironizada o rechazada del todo. Estos dois tipos de experiência (el de la identificación y el de la destrucción de la illusión), sirven para separar a los receptores de su espontánea tendencia hacia el objecto estético, provocando así su reflexión estética e moral. (1986: 283).

${ }^{6}$ John Frow (1996: 233) chama a atenção para o carácter polémico desta expressão, sobretudo pelo facto de ela surgir subsumível ao conceito de "identificação" nas categorização hierárquia realizada por R. Jauss. 
Este jogo distanciador é característico da escrita pós-modernista, e surge muitas vezes aliado à auto-reflexividade que os romances do pós-modernismo exploram de um modo intenso e reiterado ${ }^{7}$. Na obra Era Bom Que Trocássemos Umas Ideias Sobre o Assunto, o autor procede a vários jogos metaficcionais, os quais, como refere Ana Paula Arnaut (2002: 246), levam "o leitor a aceitar como verdadeira a representação do trabalho (des)construtivo que se vai expondo, mesmo que ele não passe de uma ilusão". Na verdade, neste romance, como também em Fantasia para Dois Coronéis e uma Piscina, o autor vai mostrando como se tecem os fios da intriga e como se desenham as personagens.

A este propósito, no romance Era Bom Que Trocássemos Umas Ideias Sobre o Assunto, é elucidativo o facto de o autor não atribuir logo um nome ao professor de Grego e de hesitar na escolha do nome, uma hesitação que estende até ao momento em que o desenvolvimento da personagem torna esta situação insustentável, chegando ao extremo de o autor reconhecer que a personagem já ganhou direito a reivindicar uma presença mais sólida através da atribuição de um nome - elemento fundamental de individuação:

Então aquele professor de Grego não tinha nome? Acho que já o vai merecendo, pelo seu esforçado protagonismo, a querer à força entrar nesta história . Como é que se há-de então chamar? Pensando bem ficalhe a matar Vasco Reboredo, mas não há-de passar além de seis páginas, se tanto, embora exemplares. (1999: 159)

\section{Personagens e o desnudar do fazer ficcional}

O caso mais extremo do desnudar da construção narrativa surge pelo processo da metalepse - recurso utilizado quer no epílogo de Casos do Beco das Sardinheiras, quer no diálogo com a personagem Maria das Dores em Fantasia para Dois Coronéis e Uma Piscina, como se viu em ocasião anterior ${ }^{8}$.

No caso deste último romance ainda encontramos outra forma bastante inovadora e bem mais subtil de mostrar o fazer da ficção: de

\footnotetext{
${ }^{7}$ Como esclarece Ana Paula Arnaut (2000: 233), esta utilização intrínseca e intensiva é diferente da auto-reflexividade - accionada em romances anteriores, mas apenas como "mero ornamento".

${ }^{8} \mathrm{Cf}$. informação da anterior nota 4 .

Faculdade de Letras | Universidade de Coimbra
} 
facto, dentro do próprio romance há personagens que constroem ficções criando assim uma espécie de mise en abîme do ficcional. É o caso do homem do mel que, à laia de Mofina Mendes, vai imaginando uma série de sucessos que depressa cairão por terra.

Mas, para além de certas personagens figurantes, este processo ganha relevo na construção de uma personagem bem mais importante - o muito especial Emanuel Elói, vedor e mestre de xadrez, que constantemente inventa e cria histórias: "Alto, desengonçado, com um cabelo espigado, às farripas e uma cara agaiatada, de traquinice benigna" (2003: 66) - tal era o jovem vedor e mestre de xadrez (ou "professor" de xadrez, como costumam chamar-lhe).

Como se esboça, então, o perfil desta complexa personagem? Como se enquadra no jogo ficcional inventado pelo autor?

No mosaico ficcional das personagens, trata-se de um jovem que se situa nos antípodas daquele (pseudo) jovem Nelson (cujo discurso se vislumbrou); ou seja, Emanuel Elói arranjou um modo de subsistência - é vedor - , sustenta-se a si mesmo e ao seu velho Renault Quatro e criou o seu espaço na sociedade. Não se pauta pelos valores das gerações anteriores, não acredita nelas, formou os seus próprios valores e arranjou um modus vivendi de forma a não sofrer demasiado com a sociedade que o rodeia. Há algo de epicurista na sua forma de encarar a vida, de aproveitar o que lhe vem bater à porta - a começar pelas mulheres que, gostando dele, livremente se lhe oferecem... Rejeita o prazer pelo prazer e não adere ao donjuanismo patético que lhe aconselha e pratica o seu tio. Compensa uma vida algo vulgar com toda uma força imaginativa e evasiva: inventa histórias fantasiosas que julga poderem encantar quem as escuta; porém, não é propriamente um alienado, fechado ao exterior, como nos revela o narrador: "Emanuel, apesar da juventude, como já se deixou perceber, era atento e prevenido." (p. 68)

Todavia está longe do espírito empenhado de outros tempos: Emanuel representa uma nova geração que não se interroga muito sobre os porquês, a qual, relativamente a certos aspectos, é ingenuamente crédula e em relação a outros distanciada e crítica - o que surge simbolicamente representado nesta estranha conjunção profissional de vedor e mestre de xadrez: o irracional e o racional. Como a psicologia explica, o verdadeiro vedor acredita no que faz, pelo que se coloca a hipótese de as manifestações ocorridas - a famosa vibração das varinhas de freixo ou das varas de metal para encontrar água poderem ser explicadas por algum intuicionismo que se manifesta 
psicossomaticamente ${ }^{9}$ no tremer do sujeito que, por sua vez, se comunica ao objecto. O ser 'vedor' representa o seu lado crente mas também o "desenrascar-se" em termos de ganha-pão. O xadrez representa um potencial de inteligência negligenciado e subaproveitado, num país que não prima pela sabedoria.

Ele é o representante de um tipo de geração jovem, uma geração que não acredita nos caminhos que entusiasmaram os jovens de 68 , uma geração que não sabe completamente o que quer, que anda à procura anda à procura da água, o que metonimicamente talvez signifique o que pode salvar a terra -, mas, por outro lado, uma geração que sabe bem o que não quer. Comicamente isto reflecte-se na escolha do seu nome benigno e abençoado, e na resposta que dá a Maria das Dores quando ela insinuadamente lhe pergunta:

- E de que é que gostas mais?

- Gostar, gostar, não sei bem, mas não aprecio bife com natas nem bacalhau com natas. Aliás de uma forma geral, detesto natas. (p. 67)

\section{A complexidade de um verdadeiro "céptico"}

Espreite-se agora a personagem mais densa da toda a obra de Mário de Carvalho: Lúcio Valério Quíncio, personagem que pertence ao romance histórico intitulado Um Deus Passeando pela Brisa da Tarde, onde desempenha o papel de protagonista. A sua importância define-se em grande parte pelas suas funções de magistrado - duúnviro - de Tarcisis, cidade da Lusitânia no tempo do império romano de Marco Aurélio Antonino (1994: 27), no séc. II; mas o seu relevo advém sobretudo dos seus comportamentos e do seu sentido de vida os quais são pautados pelos ideais de romanidade a que ele conscientemente alude: "Dignidade. Gravidade. Romanidade. Humanidade." (1994: 16). As suas características psicológicas são abertamente propaladas

${ }^{9}$ James Randi explica a movimentação das varas dos vedores ou a rotação dos pêndulos dos radiestesistas como decorrente de um fenómeno psicológico conhecido como «ideomotor effect» ou (à falta de melhor tradução) «efeito ideomotor», que define como: «movimento corporal involuntário originado não por uma estimulação sensorial, mas antes por uma ideia ou por um processo mental». (...) No final a «descoberta» devese simplesmente à grande probabilidade que existe de se encontrar água quando se faz uma perfuração num sítio qualquer de um terreno onde já se prevê que ela existe, isto é, precisamente aquele onde o vedor é levado a «trabalhar». Cf. Rodrigues, 2005. 
pelo decênviro Pôncio (Velutio Módio) em plena cúria que Lúcio convocara para se proceder à substituição do falecido duúnviro Trifeno. Demagogicamente Pôncio, sabedor de como dominar a assembleia, reconhece primeiramente que Lúcio é "um homem íntegro" e depois traça-lhe o elogio, mas com o fim de lhe arrojar sobre os ombros toda a responsabilidade da magistratura, impedindo a eleição, ou a cooptação de outro duúnviro:

- Proponho, cidadãos, que o duúnviro Lúcio Valério Quíncio, aqui presente, modelo de piedade, de moderação e de sageza, assuma com aprovação da cúria o duplo mandato, substituindo nas suas funções o duúnviro Gaio Cecílio Trifeno, que já viveu! (1994: 41).

Estas características funcionam por contraste relativamente aos defeitos que, por sua vez, Lúcio identifica na atitude dos decênviros: o egoísmo, a ociosidade e a pusilanimidade. Há a acresentar ainda a hipocrisia - um tema a inferir pelo leitor sobretudo a partir do episódio do pretório quando Lúcio comunica a Pôncio que, para refazer a muralha, terá de abater uma das suas casas. Louco de fúria, Pôncio atribuiu esta decisão à inveja, à prepotência, à ganância e ao abuso de poder, deixando Lúcio estupecfacto e perplexo, pensando (e o leitor juntamente com ele) que os seus concidadãos "projectavam [nele] os traços do carácter deles, como se [fossem] afinal do mesmo barro" (1994: 78). Fica assim estabelecida uma polaridade elementar do romance que permite distribuir e relacionar as personagens dentro dos valores do universo ficcional romanesco, pois elas vão ser postas à prova, face aos terríveis acontecimentos que constituem o núcleo da intriga do romance: o ataque e o cerco dos "mouros" e a resistência dos habitantes de Tarcisis.

O leitor irá comprovando ao longo do romance todas estas qualidades do protagonista, cumprindo-se assim a ideia, recuperada por Helena Buescu ${ }^{10}$, de encarar a personagem como uma proposta de sentido consistente:

...é provável que a personagem literária realize uma acção crucial na criação da "constância de sentido" no interior do texto, ao lado de outros procedimentos textuais (...) trabalhando na mesma direcção. Esta "constância de sentido" não pode, no entanto, ser entendida como

${ }^{10}$ Como esclarece Helena Buescu (1995: 105), “este conceito é proposto por Hans Hörmann (1976) e sublinhado, entre outros, por Siegfried Schmidt (1982). 
determinação apriorística e definitiva da composição da personagem, pela simples razão de que (...) a noção de progressão narrativa (Phelan, 1989) e a composição relacional de toda e qualquer personagem impedem essa fixidez enquanto princípio. (1995: 84).

Apenas o decurso do romance permitirá, de facto, corroborar as qualidades do protagonista. Caberá ao leitor ir inferindo, a partir das atitudes e decisões de Lúcio, se ele corresponde às características que lhe são atribuídas. O leitor deduzirá, então, a sua sageza não só sopesando a validade e as consequências das suas decisões, mas também a partir das ponderações e dos raciocínios que precedem ou se seguem às suas acções. Na verdade, o leitor acompanha os desafios enfrentados por Lúcio guiado pela sua mão, isto é, pela sua perspectiva e pelo seu verbo, pois que a narrativa se faz em primeira pessoa, sendo frequentes frases do tipo "Tenho toda a consciência de que todo este discurso foi um tanto injusto" (p. 156). Por este processo o leitor tem acesso aos pensamentos e sofrimentos do protagonista, nos diferentes episódios: a reunião na cúria, o discurso de Rufo na Taberna, a morte de Clélia, etc.. É através da sua perspectiva que conhecemos as outras personagens do romance e toda a teia de relações que entre si estabelecem. É, sobretudo, através da sua visão que lemos as outras personagens - não só os seus pares, como se viu, mas também Aulo, centurião ao serviço da cidade, que é a sua mão direita, Mara, sua subtil mulher, Airhan, o espião, Rufo, o padeiro, filho de liberto, ambicioso pretendente a edil (que se aproveita da situação de crise para se evidenciar e alcançar os seus desígnios), Mílquion, o chefe do grupo dos convertidos cristãos, que arrasta os seus prosélitos e também converte Iunia, a filha de Máximo Cantaber.

O lúcido e comedido Lúcio fica perplexo apenas diante desta última figura: Iunia. Ela tolhe os seus movimentos e confunde os seus pensamentos, incomoda-o ao mesmo tempo que o atrai. Reiteradamente $o$ próprio Lúcio se interroga: ter-se-á deixado “enfeitiçar" pela voluntariosa Iunia?. Aquilo que talvez possa definir melhor o desenho da personagem Iunia é aquele tal "não sei quê" - essa espécie de mais-valia estética de que nos fala Benito Feijóo (1998: 10), uma "graça oculta", -que encanta Lúcio sem ele saber porquê. Esta personagem faz jus à ideia da beleza como o que chama a atenção, como o que apela provocando ${ }^{11}$.

${ }^{11}$ Como esclarece José Augusto Mourão, é M. Ficino que ligará a beleza, kallos, ao verbo kaléo, chamar, e di-la-á provocatio. Quer dizer que toda a beleza é provocante (1998: 54). 
Para além do seu porte e dos seus olhos verdes é-nos dito que é muito linda, mas o que mais se salienta nela é uma vontade de afirmação que Lúcio lê como "obstinação" e "teimosia" (1998: 148). Um tentame de explicação mais determinista da personagem é ensaiado pelo seu velho pai Máximo Cantaber que explica a Lúcio como a morte da mãe e depois do marido a teria perturbado ao ponto de a tornar vulnerável a estranhas influências, como o cristianismo. Por outro lado, o próprio Lúcio pode testemunhar a permissividade e complacência da educação de Máximo através das atitudes de Clélia, irmã de Iunia - uma situação que irá ter consequências graves, de certa forma originando a sua terrível morte às mãos dos mouros. Mas estas explicações vão-se tornando claramente insuficientes para cingir e discernir a personagem e o modo como ela se impõe a Lúcio, tal como ele lucidamente compreende a meio da intriga:

Iunia começara por ser apenas a filha desviada do meu amigo. Um nome, uma vaga reminiscência. Um problema dele. Era agora uma companhia que eu cegamente prezava, sem saber bem porquê. Um problema meu. Impunha-se-me como que um obsidiante desafio de conseguir chegar a Iunia, à verdadeira Iunia, à humanidade de Iunia, por detrás daquele enleio espesso de frases e atitudes. (p. 166)

Toda a actuação de Lúcio vai no sentido de chamar Iunia à razão, porém, ela representa a alteridade de uma outra razão. Ela funciona como um exemplo de entrega a uma causa, opondo-se constantemente a Lúcio. Revela, porém, constância, firmeza na sua luta por uma causa que julga superior, mesmo perante a ameaça de morte. Assim sendo, o sentido desta personagem desborda para além da compreensão de Lúcio, deixando a pairar um lado residual cujo significado choca Lúcio, por se encontrar num extremo diametralmente oposto ao seu: ela figura a convicção e a crença, ele representa um modo de pensar prescrutador e, por isso, desiludido e céptico.

Para se inteligir a verdadeira profundidade deste cepticismo é necessário ver como ele decorre da avaliação que Lúcio faz do xadrez das diferentes personagens que o rodeiam.

Airhan - um informador dos magistrados -é, ao fim e ao cabo, um espião. É caracterizado directamente pelo narrador Lúcio e é sob a sua perspectiva avaliativa que tal personagem nos é apresentada. Cheirava mal e apresentava-se com um "vestuário compósito, quase andrajoso, barba caótica, tronco espesso, braços curtos, [como] os trabalhadores de portos". Marca a sua presença pelo cheiro impestante 
e salienta-se pela sua cobiça, pela sua labilidade e habilidade em proveito próprio.

$\mathrm{Na}$ complexidade do romance, até a certa altura, uma outra personagem parece estabelecer o contraponto com esta: trata-se de Aulo Mâncio, o centurião ao serviço da cidade e prefeito às ordens do pretório (p. 35), sempre tão rígido na sua "soturnidade discreta", sempre de uma "fidelidade tão constante e humilde". Ora, no contexto de corrupção de um império romano dissoluto, a presença de alguém sempre tão respeitador das diferenças de estatuto faz com que Lúcio se interrogue sobre o seu "conformismo": "Quem era este Aulo, afinal?" (p. 198). Esta interrogação mostra bem como as personagens se vão configurando ao longo da ficção e como a sua "individuação" (no sentido conceptual de configuração das personagens acima referido) ${ }^{12}$ depende do jogo relacional não só entre a intriga e as personagens como também entre as próprias personagens. A esta interrogação de Lúcio, levantada a meio da acção (no capítulo XII), sobrevirá a constatação, lá mais para o final do romance, das verdadeiras motivações que determinam o seu comportamento ${ }^{13}$ que mais do que servidor se revela servilista e marca a personagem como "vira-casacas". Por seu turno, o ponto de vista funcionalista de análise das personagens pode ser aqui bem esclarecedor já que ele passa de adjuvante a oponente. É mais um conterrâneo que cede à corrupção e se deixa seduzir por galas e gloríolas: aliciado pelo senador Calpúrnio (que lhe promete o comando da $1^{a}$ coorte dos centuriões - o primipilato) trai a confiança de Lúcio e conluia-se com os decênviros. Funciona como mais uma acha no descrédito que Lúcio vai acumulando sobre os cidadãos romanos.

Será esta apenas uma entre as muitas traições dos decênviros ${ }^{14}$ e dos senadores de Tarcisis, os quais, movidos pela corrupção, pela vontade de vingança e por uma mesquinha, reles e cruel concepção da romanidade e dos seus ritos, funcionam, durante toda a intriga, como oponentes do espírito de cidadania que determina a acção política de Lúcio, pautada por um sentido de rectidão e de justiça. No final chegam mesmo a torpedear Lúcio encontrando-se, pela calada da noite, com Scauro, o comandante da VII Legião e ajudante do procurador imperial,

${ }^{12}$ Cf. Uri Margolin, 2005: 55.

${ }^{13}$ Insinua-se, por exemplo, que o comportamento que o leva provavelmente a matar o esquálido poeta Lúculo Cornélio seja motivado por ciúmes relativamente a Galla, sua mulher.

${ }^{14}$ Chamava-se Decênviro, em Roma, sob a República, a cada um dos dez membros de um tribunal permanente encarregado de julgar os processos relativos à liberdade. 
para intrigar contra ele e denegrir a sua pronta, enérgica e corajosa acção que evitara a tomada de Tarcisis pelos "bárbaros".

Mílquion é, no romance, o bispo dos cristãos: anda difundindo a ideia do Deus salvador e tentando aumentar o número de prosélitos. É visto como um oportunista - até por Aulo que o avalia como "um caçador de oportunidades" (p. 157) - é um estrangeiro - sírio, embora segundo Lúcio mais parecesse "um macedónio, ou um lídio pois não tinha feições asiáticas. É alto, de traços regulares e tem os olhos claros e cabelos crespos e cinzentos, "barba emaranhada, cinzenta e descuidada". A descrição física desta personagem é feita com algum pormenor, principalmente por dois motivos: primeiro, ao nível interno, essa descrição permite infundir no leitor, subrepticiamente, uma ideia da idade do próprio Lúcio, pois ele diz que o estrangeiro tem mais ou menos a idade dele, e como Mílquion tem os cabelos cinzentos o leitor depreende que Lúcio esteja na maturidade; em segundo lugar, esta descrição permite estabelecer a diferença do estrangeiro relativamente ao "padrão" da romanidade. Lúcio repara nas suas mãos "largas e nodosas" e a partir deste pormenor desduz que ele "já tinha vivido sete vidas (...) e nem todas bem vividas...". Este pormenor liga a descrição física à psicológica e vai incutir no leitor alguma desconfiança relativamente à profundidade e seriedade das suas motivações, já que Lúcio detecta nele uma "arrogância tranquila, impante de falsa ciência, dizedora de frases, pairando acima dos destinos do mundo" (p. 156), e como tal, considera-o um "farronqueiro" (p. 147). A pouca fiabilidade desta personagem advém do facto de ir crescendo em proporção inversa a fiabilidade que o leitor deposita em Lúcio. Como Lúcio o vê com desconfiança, tal impede a identificação do leitor com esta personagem e, por extensão, com o que ela representa $-\mathrm{o}$ mundo do pensamento cristão, um mundo ideológico e religioso diferente, cujos princípios não convencem Lúcio. $\mathrm{O}$ facto de ser diferente, de carrear uma lógica diferente, alerta Lúcio para a situação de não-diálogo, de choque cultural, deixando assim em aberto, no romance, a representação de uma fractura, uma grande divisão nas formas de pensar. Cabe assim ao leitor um jogo abdutivo ${ }^{16}$, através do qual ele terá de inferir o carácter da personagem Mílquion, terá de avaliar a força persuasiva da crença cristã e deverá ajuizar o modo tenaz e os meios algo ínvios escolhidos para implantar crença (à semelhança do acontecerá com qualquer outra crença).

\footnotetext{
${ }^{15}$ Lídia, uma região da Anatólia, hoje Turquia.

${ }^{16}$ Cf. Uri Margolin, 2005: 55.
} 
Por tudo isto, Lúcio é uma personagem cuja complexidade se desenrola, se desdobra e se abre paulatinamente ao leitor. As suas qualidades de homem íntegro cativam desde o início o leitor que com ele rapidamente se identifica. (É curioso até pensar como mesmo as pessoas más facilmente de identificam com os "bons" da história...). No seu caso, esta identificação prossegue em crescendo até ao final do romance, concorrendo para tal o facto de ele próprio ser o narrador, como já se referiu, e de ser configurado pelo autor como um narrador fiável. Se este processo permite o acesso aos seus pensamentos, às suas próprias, incertezas e autocríticas é porque, a montante, o autor escolheu construir mimeticamente a personagem representando um homem pensante; por seu turno, a jusante, o leitor faz a leitura mimética da personagem passando por diferentes graus da identificação tal como foram identificados por Jauss: admirativa, simpatética e catártica. De facto, o poder raciocionante da personagem, assim todo desvelado perante todo o leitor, torna-a impressionante e causa admiração: os seus combates entre sentimento e razão, os seus constantes exercícios de autocontrolo originam um progressivo envolvimento do leitor com a personagem.

Amiúde, os exercícios racionalizantes do protogonista misturamse com sentimentos e desejos que desenham a parte emotiva da personagem. Lúcio deseja ver Iunia, a sua presença causa-lhe prazer - embora algo amargo e estranhamente dorido. Lúcio só não é mais voyeurista porque o seu super-ego limita o recorte do seu prazer a uma mediania platónica e pelo facto de ele se aperceber da escopofilia de Iunia, ou seja, do seu desejo de se ver observada. Esta é uma forma de "identificação cinemática em relação ao prazer visual"17 (que a ficção cinematográfica tanto explora - basta pensar no célebre filme A Janela Indiscreta de Alfred Hitchcock); por sua vez, o leitor identifica-se com esta vivência perturbada de Lúcio a qual lembra como "tão contrário a si mesmo é Amor", como ele provoca esse "contentamento descontente" - esse sentir contraditório que o leitor provavelmente já experienciou e que ficcionalmente revive.

Mas, em toda a identificação do leitor com esta personagem, há uma peculiaridade: é que, com o inteligente Lúcio, os leitores vão aprendendo a criar uma distância avaliativa relativamente às outras personagens, vão ganhando uma espécie de sabedoria - quais "sábios

${ }^{17}$ John Frow (1986: 239) fala destes tipos de identificação chamando a atenção para o contributo deste tipo de abordagem psicologizante. 
incautos" - treinados pela sua ironia coleante, a qual permeia a sua apreciação dos que lhe são próximos, das suas ínvias aspirações e das suas mesquinhas existências. Exemplo desta ironia é a penúltima senha (bebida em Virgílio) que dá a Aulo depois da sua traição: "Tão mudado do que era..." (p. 295)

Lúcio, como personagem, atinge assim uma dimensão mais vasta, um nível de leitura superior, não só porque representa uma "ideia" do mundo, claramente humanista e uma visão do seu tempo, marcada por um ideal de romanidade e cidadania, mas também porque a abstracção gerada a partir destas ideias lhe confere uma amplitude universalizante. Como se isto não bastasse, Lúcio representa ainda a questionação da crença, que se plasma através do seu desajuste com a crença cristã e/ ou pagã, redundando nesse seu cepticismo profundo - que faz dele um verdadeiro "céptico". Na verdade, não só não acredita nos deuses (sejam eles quais forem) como não acredita nos homens, por isso o seu confronto com Iunia é tão doloroso e penoso: é o choque entre o descrente e o religioso, bem vívido ainda no nosso mundo actual.

Porventura é o facto de a este descrédito se somar a desilusão que lhe traz a ordem de dar prisão aos cristãos enunciada por Marco Aurélio Augusto - uma personalidade com a qual sentira afinidade pois nele pressentira uma idêntica descrença relativamente a esta questão dos ritos e espectáculos populistas - que o leva, em determinado momento, a ser atraído pelo suicídio, fazendo balancear o cepticismo lúcido por que se rege. Mas, nesse momento, eis a pergunta que a si próprio dirige:

Iria eu atraiçoar derradeiramente o lema de Epicteto ${ }^{18}$ que sempre quisera - com tanto insucesso - adoptar como norma de vida "Tem-te! Aguenta!" (p. 287).

Finalmente, em Lúcio, cujo nome, claramente simbólico, vem de luz ${ }^{19}$, vence o estoicismo.

Antes do julgamento dos cristãos que será obrigado a conduzir, faz um sacrifício propiciatório, confessando que essa é a linguagem

${ }^{18}$ No antepenúltimo capítulo (p. 279) há mais uma referência a Epicteto, corroborando assim de forma explícita a presença do seu ensinamento.

19 "Lúcio Latim (Lux). Luz. Nascido com o dia, Nascido com a manhã. Lúcio: Significa luz e indica uma pessoa preocupada em esclarecer todo mundo ao seu redor. Gosta muito de crianças e pode se realizar como professor. Seu ideal é ter uma vida familiar segura e sem atritos. 
que tem para comunicar com a Providência. Dirige o ofertório à Justiça, mas evoca também o Deus cristão de Iunia (p. 296), aproximando da ideia de Cristo de Ricardo Reis - Cristo é apenas o deus triste que faltava.

O pensamento de Maquiavel ecoa também neste cepticismo, sobretudo no final, pois o não-reconhecimento por parte dos seus concidadãos das suas acções que salvaram a cidade (e o seu consequente exílio) advém do facto de ele não ceder ao jogo de agradar às massas. $\mathrm{O}$ facto de ele não condescender com o populismo fácil e de rejeitar a aura enganadora de um ritualismo religioso supercifial ser-lhe-á fatal. De certa forma o narrador no final apercebe-se de que o sentimento religioso não sobrevive sem ritos (sintomatologia que Fradique Mendes já diagnosticara e para a qual também alertara Guerra Junqueiro ${ }^{20}$ ). Também no que diz respeito à política, só com uma muito desejada e esperada distribuição de louros e benesses, um político perdurará no poder. Por isso, a última senha que Lúcio dá a Aulo ${ }^{21}$ antes de partir para o exílio é também irónica: “aura popular...” (p. 295).

Finalmente caberá a Lúcio, e aos leitores que com ele se identifica(ra)m, acatar a lição de uma máxima de Epicteto, que a personagem por certo intuiu:

Lembra-te que és actor numa peça, curta ou longa, onde o autor te quis fazer entrar. Se ele quer que desempenhes o papel de um mendigo, é necessário que o faças o melhor que te seja possível. (...) Porque é a ti que cabe desempenhar a personagem que te foi dada; mas é a um outro que cabe escolher a personagem.

${ }^{20}$ Também Jacinto, juntamente com a Odisseia, preserva o Manual de Epicteto.

${ }^{21}$ Não será por acaso que o significado de Aulo, do latim Aulus, é "velho". 


\section{Bibliografia}

A. P. Arnaut, Post-Modernismo na Literatura Portuguesa Contemporânea (Coimbra, Almedina, 2002).

D. Bougnoux, "Le principe d'identification", in Personnage et Histoire Littéraire (Toulouse, Presses Universitaires du Mirail, 1991), pp. 187-195.

H. Buescu, A Lua, a Literatura e o Mundo (Lisboa, Cosmos, 1995).

M. de Cavalho, Casos do Beco das Sardinheiras (Lisboa, Caminho, 1982).

M. de Carvalho, Fantasia Para Dois Coronéis e Uma Piscina (Lisboa, Caminho, 2003).

B. Feijóo, Um Não Sei Quê (Lisboa, Vega, [1746], 1998).

J. Frow, "Spectacle Binding: On Character", in Poetics Today (Vol. 7, n², 1986) pp. 227-250.

G. Gennete, L'Euvre de l'Art. La Relation Esthétique (Vol. II, Paris, Seuil, 1997).

G. Genette, Métalepse (Paris, Ed. Seuil, 2004).

J. F. Hoorn and Elly A. Konijn, "Perceiving and experiencing fictional characters: An integrative account", in Japanese Psychological Research (Vol. 45, N4, 2003), pp. 250-268.

H. R. Jauss, Experiencia y Hermeneutica Literaria. Ensayos en el campo de la experiencia estética (Madrid, Taurus, [1977], 1986.

U. Margolin, "Character", D. Herman; M. Jahn; M-L. Ryan - Routledge Encyclopedia of Narrative Theory (London/New York, Routledge, 2005), pp. 54-57.

G. Mead, "The Representation of Fictional Character", in Style (Vol. 24, n³, 1990), pp. 440.

P. Mexia, "O Manuel Germano", in Diário de Notícias. Artes (17 de Junho, 2005) http://dn.sapo.pt/2005/06/17/artes/o_manuel_ germano.html

J. A. Mourão, "Posfácio”, a Feisóo, Benito - Um Não Sei Quê (Lisboa, Vega, 1998).

L. G. Rodrigues, "A Radioestesia” (2005) in http://rprecision.blogspot. com/2005/06/radiestesia.html

J.-M. Schaeffer, L'art de l'âge moderne. L'esthétique et la philosophie de l'art du XVIIIème siècle à nos jours (Paris, Gallimard, 1992).

M. Seel, "Le langage de l'art est muet", in Ch. Bouchindhomme; R. Rochlitz (dir.) L'art Sans Compas. Redéfinitions de l'Esthétique (Paris, Éd. du Cerf, 1992). 
M. J. Simões (2006) “Atrevidas e desbordantes: as personagens em Mário de Carvalho", in Figuras da Ficção (Coimbra, Centro de Literatura Portuguesa, 2006), pp. 79-92.

A. Thomasson, "Fictional Characters and Literary Practices", in British Journal of Aesthetics (Vol. 43, n' 2, April, 2003), pp. 138-157.

$\mathrm{K}$. Walton, Mimesis as Make-Believe: On the Foundations of the Representational Arts (Cambridge Mass., Havard University Press. 1990). 